\title{
A Comparison of Three Cold-climate Strawberry Production Systems: Environmental Effects
}

\author{
Matthew D. Stevens ${ }^{1}$ \\ Department of Plant Science and Landscape Architecture, University \\ of Maryland, Plant Sciences Building, College Park, MD 20742
}

Brent L. Black

Plants, Soils and Climate Department, Utah State University, Logan, UT 84322-4820

John D. Lea-Cox

Department of Plant Science and Landscape Architecture, University of Maryland, Plant Sciences Building, College Park, MD 20742

\section{Ali M. Sadeghi, Jennifer Harman-Fetcho², Emy Pfeil, Peter Downey, Randy Rowland, and Cathleen J. Hapeman ${ }^{3}$ \\ Beltsville Agricultural Research Center, Agricultural Research Service, U.S. Department of Agriculture, 10300 Baltimore Avenue, Beltsville, MD 20712}

Additional index words. advanced matted row, Fragaria $\times$ ananassa, erosion, pesticide, plastic mulch, nitrogen uptake, nitrogen use efficiency

\begin{abstract}
The environmental effects of the three strawberry (Fragaria $\times$ ananassa) coldclimate production systems were compared: the traditional method of conventional matted row (CMR) and the two more recently developed practices of advanced matted row (AMR) and cold-climate plasticulture (CCP). Side-by-side field plots were instrumented with automated flow meters and samplers to measure and collect runoff, which was filtered and analyzed to determine soil, pesticide, and nitrogen losses. Although annual mean runoff volumes were similar for all three production systems, the soil losses from CMR plots were two to three times greater than the CCP plots throughout the study and two to three times greater than the AMR plots only in the first year of the 3-year study. In general, decreases in erosion and runoff volumes were observed in plots that were disturbed less by machine operations and had less foot traffic as a result of decreased need for hand weeding and in the plots that used straw mulch in the furrows between the beds. Timing and intensity of precipitation events also influenced the amount of soil erosion. Pesticide residues and nitrogen losses were also greatest in the runoff from the CMR plots. The two systems that used drip fertigation, AMR and CCP, also had higher nitrogen uptake efficiencies. Overall, the CCP and AMR systems performed similarly for most criteria; however, considering the nonrenewable nature of the plastic mulch and the need to dispose of the plastic mulch in a landfill, the AMR system was more environmentally sustainable than the CCP system.
\end{abstract}

Strawberries presently rank fifth in the United States behind bananas, apples,

\footnotetext{
Received for publication 7 May 2008. Accepted for publication 24 Sept. 2008.

We thank the North American Strawberry Growers Association for financial support of this research, Phillip Edmonds for field maintenance and pesticide application, and Dr. Dennis Timlin for assistance with statistical analysis.

This paper is a portion of a Master's Thesis submitted by M. Stevens.

Use of trade names does not imply an endorsement of the products named or criticism of similar ones not named.

${ }^{1}$ Current address: Horticulture Agent, NC Cooperative Extension Service, 359 Ferrell Lane, Halifax, Nova Scotia, Canada.

${ }^{2}$ Chemist, formerly with USDA-ARS.

${ }^{3}$ To whom reprint requests should be addressed; e-mail cathleen.hapeman@ars.usda.gov.
}

included in statistical reports. The popularity of these direct-market farms is increasing as a result of the expanding local food movement. One of the premises behind this movement is that eating locally grown food is better for the environment, yet little is known about how cold-climate strawberry production affects the environment.

The conventional matted row system $(\mathrm{CMR})$ is a perennial system and has been the primary method for strawberry production in these regions for much of the past century. More recently, cold-climate plasticulture (CCP) (http://plasticulture.cas.psu. edu/nraes_manual.htm) has become popular. Both CCP and CMR use methyl bromide fumigation and other pesticides to control replant disorders. However, methyl bromide and other traditional pesticides are being phased out as a result of the restrictions mandated in the Montreal Protocol of 1985 (http:// www.epa.gov/ozone/intpol/index.html) and the Food Quality Protection Act of 1996 (http://www.epa.gov/pesticides/regulating/laws/ fqpa/), prompting the development of alternative production strategies to manage these pest pressures such as advanced matted row (AMR) (Black et al., 2002a, 2002b). New production practices should be evaluated for improvements in sustainability such as the ability to conserve soil and water and to reduce the movement soil, nutrients, and pesticides from the production fields to nearby water resources. From these evaluations, guidelines and strategies can be developed and revised to address the standards associated with the Clean Water Act and the implementation of the TMDL (Total Maximum Daily Load) program (USEPA, 1994, 1998).

Pesticides, nutrients, and suspended soil particles in runoff have been shown to have significant negative effects on aquatic plants (Forney and Davis, 1981; Jones and Winchell, 1984) and estuarine organisms (Clark et al., 1993; Savitz et al., 1994; Scott et al., 1994). Bactericides, insecticides, and fungicides, which are frequently used to protect fruit crops, are known to have more adverse effects on finfish, shellfish, and other aquatic organisms at environmentally relevant concentrations as compared with the herbicides used on grain crops (Pait et al., 1992). In most cases, $\approx 1 \%$ to $6 \%$ of applied pesticides in row crop production systems can be transported off-site in runoff water and on soil particles in the runoff (Wauchope, 1996); however, losses of nearly $40 \%$ of the applied pesticide have been observed with some vegetable production systems (Rice et al., 2002).

In general, the amount of pollutants transported in runoff from fields depends largely on the slope of the field, soil type, management practices, presence or absence of subsurface drains, and the amount, timing, and the intensity of rainfall after application of nutrients or pesticides (Bengston et al., 1990; Leonard et al., 1979; Poling and Monks, 1994; Triplett et al., 1978). Field runoff with its pollutants enters nearby streams affecting water quality at the watershed level and ultimately at the basin scale. 
For example, sediment loading into the Chesapeake Bay has been cited as a leading cause of submerged aquatic vegetation degradation and habitat loss for shellfish and fish species (Brush and Hilgartner, 2000). Nearly 40\% of the nutrient loadings to the Chesapeake Bay have been attributed to agriculture (http://www. chesapeakebay.net/assess/2006_health.htm). Excess nutrients have led to algae blooms and anoxic zones in the Bay and have contributed to the decline of overall Bay health. Many states in the northeastern United States have, or are considering enacting, a nutrient management policy for all sectors of agriculture to reduce nutrient runoff and leaching (Lea-Cox and Ross, 2001).

When identifying best management practices for strawberry production, soil conservation measures, nitrogen $(\mathrm{N})$ applications, and pest management strategies need to be considered in a more holistic approach. The present multiyear field study was carried out to compare the environmental footprint of three cold-climate strawberry production systems: CMR, AMR, and CCP. Runoff, plant, and fruit samples were collected during each of the growing seasons. Runoff samples were analyzed for total runoff and soil, pesticide, and nutrient losses. Plant and fruit samples were used to evaluate nutrient uptake efficiencies associated with each of the respective production methods.

\section{Materials and Methods}

\section{Site description and instrumentation}

The research site was located at the Henry A. Wallace Beltsville Agricultural Research Center (Beltsville, MD). The site was comprised of Mattapex silt loam (fine-silty, mixed, active, mesic Aquic Hapludult with $1.3 \%$ to $1.6 \%$ organic carbon content) and had a $5.2 \%$ to $7.1 \%$ north-south slope. Although this slope range is much higher than the recommended slope range of $1 \%$ to $2 \%$ for production in the mid-Atlantic United States (Poling and Monks, 1994; O'Dell and Williams, 2000) and 3\% to $5 \%$ in the northeast United States (Pritts and Handley, 1998), the site was purposely selected to facilitate the collection of runoff water. The site was divided into nine side-by-side research plots of nearly identical size, measuring $13.7 \mathrm{~m}$ long $\times 6.1 \mathrm{~m}$ wide, that were assigned to one of three replicate plots for each of the three production systems: CMR, AMR, and CCP. Experimental treatments were established using a randomized complete block design with blocking by location and plot history. Before this study, the plots were in a sweet corn (Zea mays)-tomato (Lycopersicon esculentum Mill) rotation.

Advanced matted row. In the fall before Year 1 (Fall 2001), raised beds were formed in the AMR plots with subsurface drip irrigation lines placed at a depth of 5 to 8 $\mathrm{cm}$; the beds were immediately seeded with a winter cover crop of hairy vetch (Vicia villosa Roth), grain rye (Secale cereale), and crimson clover (Trifolium incarnatum). Three weeks before strawberry planting, glyphosate (Roundup Original; Monsanto, St. Louis, MO) was applied to the cover crop. A week later, the cover crop residue was mowed down creating a vegetative residue layer or mat. On 12 May 2002, dormant bareroot 'Allstar' strawberry plants were handplanted through the residue layer. This residue layer provided some weed suppression during strawberry establishment with the remaining weeds controlled by hand weeding and spot applications of paraquat (Gramoxone Max; Syngenta, Greensboro, NC). In the fall of Year 1, the strawberry beds were narrowed (runners removed from furrows) with directed application of paraquat. The AMR system is described more fully elsewhere (Black et al., 2002; Stevens, 2005).

Conventional matted row. CMR plots were prepared in March of Year 1. Dormant bare-root 'Allstar' strawberry plants (Nourse Farms, South Deerfield, MA) were set at a spacing of $45 \mathrm{~cm}$ within row and $1.5 \mathrm{~m}$ between row centers. Overhead irrigation was delivered using gear-driven lawn sprinklers placed along the edges of each plot. Plots were cultivated periodically to control weeds with hand weeding around mother plants and hand placement of runners.

Cold climate plasticulture. In August of Year 1 (2002), CCP plots were prepared with raised beds covered with 1.25 -mil black plastic mulch with subsurface drip irrigation lines placed at a depth of 5 to $8 \mathrm{~cm}$ down the center of the beds. 'Allstar' plug plants (Davoncrest Farms, Hurlock, MD) were planted through the plastic mulch in offset double rows at a $30-\mathrm{cm}$ within-row and between-row spacing. Weeds between beds were controlled by directed application of paraquat.

Fruit was harvested from each system in spring of Years 2 and 3 (2003 and 2004). After harvest in Year 2, the plots were renovated to retain high production for a second year. For the CMR and AMR systems, renovation consisted of mowing down plants to remove leaves, application of 2,4-D (2,4-D 6 Amine; NuFarm Turf \& Specialty, Burr Ridge, IL), and a period of dormancy followed by application of ammonium nitrate. For the CCP system, renovation consisted of removal of leaves using a weed trimmer and removal of excess branch crowns. Very few plants were found to have more than five crowns and therefore were not considered in excess.

\section{Pesticide and fertilizer application}

Each production system was treated with an identical bloom-time fungicide spray regime following the recommendations of the Maryland Commercial Small Fruit Production Guide (Steiner et al., 1999). All fungicides were applied using an experimental plot sprayer equipped with a single-row boom with three nozzles directing spray from above and both sides of the row. In Year 2, azoxystrobin (Quadris Flowable; Syngenta, Greensboro, NC), benomyl (Benlate; DuPont Agricultural Products, Wilmington, DE), captan (Captan 50-WP; Micro Flo, Lakeland,
FL), and thiophanate-methyl (Topsin-M WSB; Cerexagri, King of Prussia, PA) were applied to control the following diseases: Botrytis rot (Botrytis cinerea Pers.:Fr), anthracnose (Colletotrichum acutatum J.H. Simmonds), common leaf spot [Mycosphaerella fragariae (Tul.) Lindau], Phomopsis leaf blight [Phomopsis obscurans (Ellis \& Everh.) Sutton], and leaf blotch (Gnomonia comari $\mathrm{P}$. Karst. and Gnomonia fragariae Kleb.). The same group of fungicides, except for benomyl, which was no longer available commercially, was used in Year 3. Specific application dates are given elsewhere (Stevens, 2005). Herbicides were applied to each plot as needed and in concert with other weed management practices appropriate for that system. A group of insecticides was identified for potential use and plots were scouted on a regular basis. Minimal insect infestation was observed, so no insecticide applications were necessary during the course of the experiment.

Although between-row weed control in the CMR system was primarily accomplished through mechanical cultivation, the CCP and AMR systems were treated when necessary with paraquat. On one occasion, the CMR system also received an application of paraquat. Additionally, the CMR and AMR systems received one application each of 2,4-D during renovation after harvest in Year 2. Paraquat and 2,4-D were applied using a backpack sprayer and glyphosate by a boom sprayer. The rate and number of pesticide applications is shown in Table 1.

Fertilizer application rates, timing, and method differed in each system according to recommended practices for that system. Ammonium nitrate was broadcast in one to two large applications each year to the CMR, whereas the AMR and CCP systems received weekly fertigations through the drip irrigation system.

\section{Precipitation and frost protection}

A weather station located within $0.5 \mathrm{~km}$ of the research plots was used to measure the time and intensity of each precipitation event using a tipping-bucket rain gauge. Temperature, solar radiation, and wind speed and direction were also recorded at 15-min intervals. All runoff data reported here were from precipitation events with the exception of 24 Apr. 2003 and 16 Apr. 2004. Runoff samples collected on these dates were the result of frost protection activities. To protect strawberry flower buds from frost that occurred before fruit set, overhead irrigation was applied equally to all three production systems when the temperature dropped below $2{ }^{\circ} \mathrm{C}$.

\section{Runoff and groundwater collection}

Earthen berms were constructed around each plot to prevent water movement between the plots and to capture runoff from only the three middle furrows within each four-bed plot. Automated runoff samplers (Model 6700; Isco, Lincoln, NE) installed at the edge of each plot were equipped with a bubbler flow module (Model 730) and were programmed to collect samples on a 


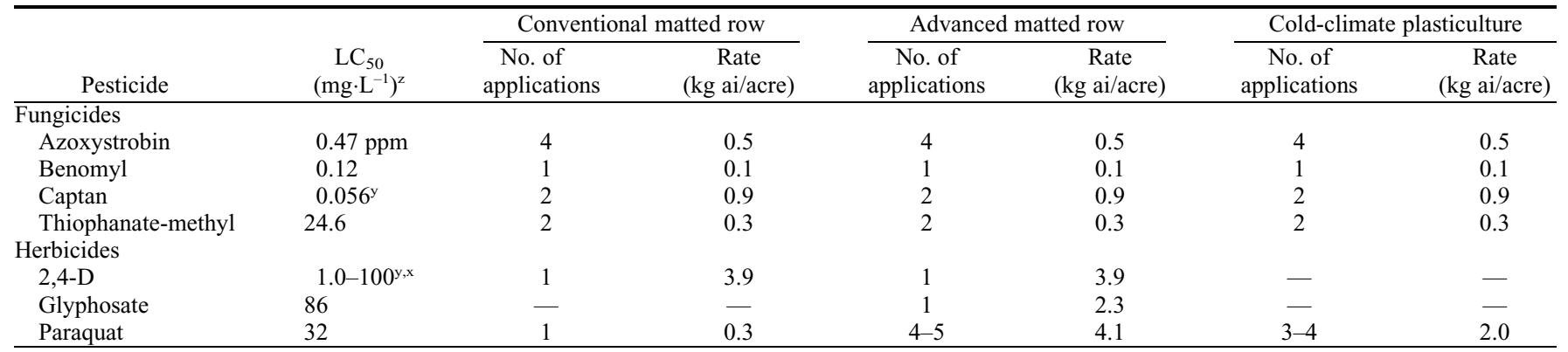

${ }^{{ }^{2} C_{50}}(96 \mathrm{~h})$ listed are for rainbow trout (Oncorhynchus mykiss) except as noted (http://toxnet.nlm.nih.gov/index.html).

${ }^{\mathrm{y}} \mathrm{LC}_{50}(96 \mathrm{~h})$ listed are for cutthroat trout (Oncorhynchus clarki).

${ }^{\mathrm{x}} \mathrm{LC}_{50}$ varies with formulation.

flow-weighted (volume) basis as runoff was directed through a fiberglass $\mathrm{H}$-flume.

Subsurface samples were collected using suction lysimeters (Model SPS210031; Earth Systems Solutions, Lompoc, CA). Two lysimeters were placed in the southern half of each plot at a depth of $50 \mathrm{~cm}$ and periodic soil water samples were collected from below the rooting zone using a vacuum collection device. Samples were stored at $4{ }^{\circ} \mathrm{C}$ until analysis.

\section{Sample processing and analysis}

Runoff samples were filtered through a preweighed $0.45-\mu \mathrm{m}$ pore size membrane filter to determine the amount of total suspended solids from each plot. The filters were baked at $60{ }^{\circ} \mathrm{C}$ overnight and reweighed. An aliquot of each filtered runoff sample was analyzed for nitrate and ammonium using a flow injection analyzer (Quick Chem Automatic Flow Injection Ion Analyzer \#8000; Lachat, Loveland, CO) equipped with a colorimetric detector. A second aliquot from each of the filtered runoff samples was analyzed for pesticide concentration using high-performance liquid chromatography with multiple reaction monitoring (MRM) dual mass spectral analysis.

The chromatographic separations were accomplished using a Waters (Milford, MA) Alliance 2690 quaternary pumping/automatic liquid sampler system equipped with a Waters YMC ODS-AQ (120A pore size; $53-\mu \mathrm{m}$ particle size) 10 -cm column ( $2 \mathrm{~mm}$ i.d.) heated to $40{ }^{\circ} \mathrm{C}$; mobile phase flow rate was 0.2 $\mathrm{mL} \cdot \mathrm{min}$. An isocratic elution with $65: 25: 10$ methanol:aqueous formic acid $(0.1 \%)$ :acetonitrile was used for azoxystrobin, benomyl, and thiophanate-methyl separations. Samples were also analyzed for captan, 2,4-D, and paraquat using a mobile phase gradient of 50:30:15:5 to $80: 0: 15: 5$ methanol:water:aqueous formic acid $(0.1 \%)$ ):acetonitrile (polynomial curve 9) over 8 min with a 7 -min final hold. Glyphosate analyses were not performed because glyphosate was used only once and applied only to the AMR plots.

A Micromass (Milford, MA) Quattro Ultima triple quadrupole mass spectrometer system with positive ion atmospheric pressure chemical ionization was set to run in MRM mode using argon collision gas. The ionization source and desolvation zone temperatures were set to 120 and $500{ }^{\circ} \mathrm{C}$, respectively. Nitrogen desolvation and cone gas flows were set to $275 \mathrm{~L} / \mathrm{h}$ and $100 \mathrm{~L} / \mathrm{h}$, respectively. The detector voltages for all analytes except captan were $0.2 \mu \mathrm{A}, 35 \mathrm{~V}$, and $15 \mathrm{~V}$ for corona, cone, and collision, respectively. For captan, the detector voltages were $4 \mu \mathrm{A}, 35 \mathrm{~V}$, and $9 \mathrm{~V}$ for corona, cone, and collision, respectively. The parent and daughter ions (MS1 and MS2; in Da) monitored in the MRM transitions were: 2,4D, 217.25, 171.18; azoxystrobin, 404.30, 372.10; benomyl, 192.20 , 160.10; captan, 302.12, 266.04; paraquat, 186.31, 171.19; and thiophanate-methyl, 343.23, 151.14. Quantification was by least squares linear regression analysis of the peak area versus amount (ng)
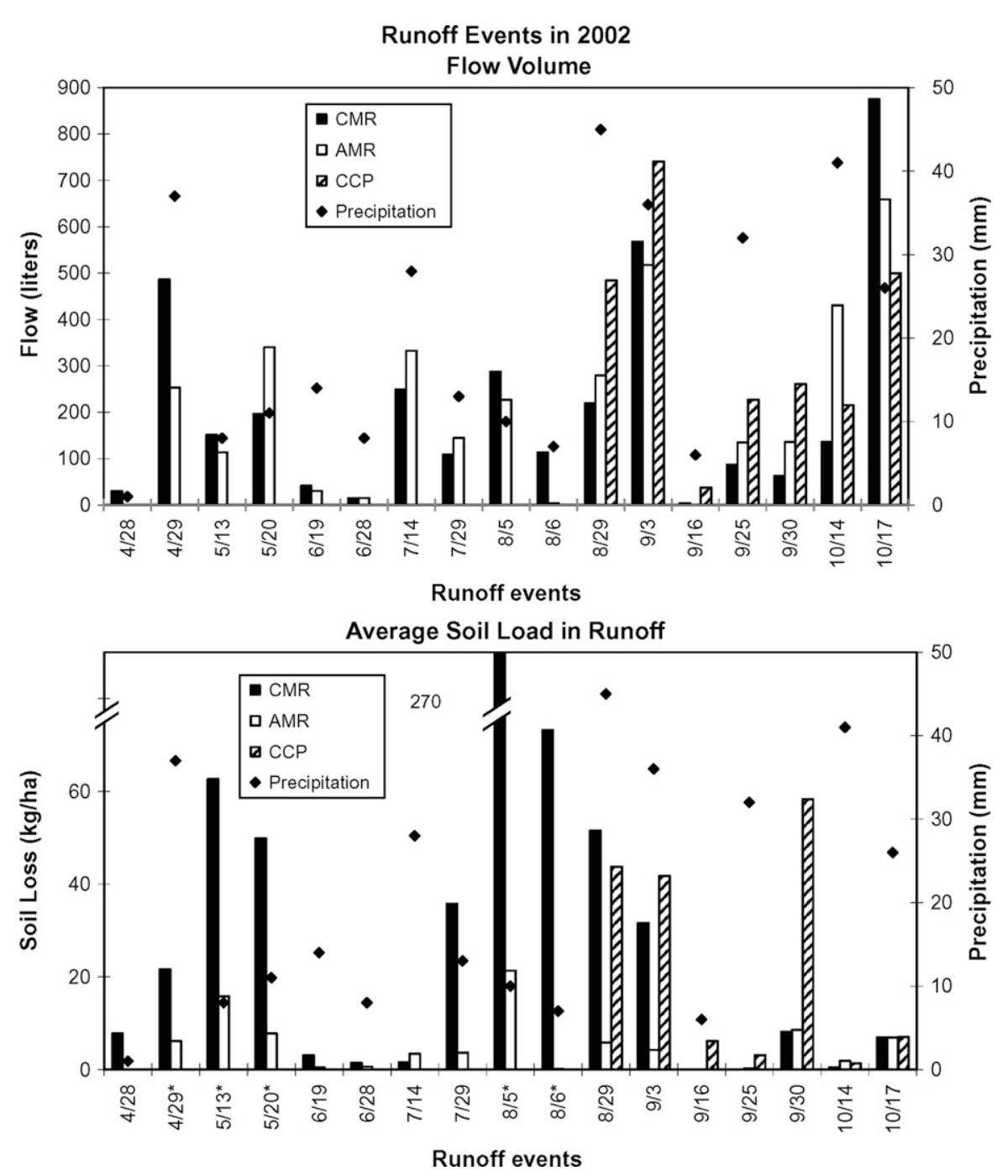

Fig. 1. Precipitation and average runoff volume and respective soil loss in runoff from each production system per event in 2002. Asterisk after date indicates that difference is significant between at least two treatments in runoff event. $\mathrm{CMR}=$ conventional matted row; $\mathrm{AMR}=$ advanced matted row; $\mathrm{CCP}=$ cold-climate plasticulture. 
injected on-column using four external standard calibration curves. The limits of detection were $0.1 \mathrm{ppb}$ for azoxystrobin, benomyl, and thiophanate-methyl; $12 \mathrm{ppb}$ for captan and paraquat; and $170 \mathrm{ppb}$ for 2,4-D.

\section{Plant carbon and nitrogen analysis}

After fruit harvest in Years 2 and 3, the plants within four $0.093 \mathrm{~m}^{2}(1 \mathrm{sq} \mathrm{ft})$ sections of each plot were destructively harvested. These squares were used as representative sample areas as a result of the differences in plant spacing and growth habit among systems. For the CCP system, one mother plant was present in each harvested square, whereas the CMR and AMR squares contained one mother plant along with several daughter plants. Plant tissue from each harvested square was then separated into leaf, crown, runner, root, and fruit truss. Fresh weights were taken for each tissue type and the number of leaves, crowns, trusses, and runners was recorded. Runners and trusses were further separated to isolate leaves associated with each, thus designated as runner leaves and truss leaves with all other leaves designated as crown leaves. Leaf area was then taken on runner leaves, truss leaves, and crown leaves. A 10-leaf subsample was taken from all crown leaf samples (with the exception of one sample, which only had 13 total leaves), and a subsample was taken for any other tissue sample exceeding $40 \mathrm{~g}$ fresh weight.

Tissue subsamples were frozen in liquid nitrogen, stored at $-80{ }^{\circ} \mathrm{C}$, and then freezedried using a LabConco Model 77550 Lyophilizer (LabConco Corporation, Kansas City, $\mathrm{MO})$. The remaining plant samples were oven-dried at $60{ }^{\circ} \mathrm{C}$ for $72 \mathrm{~h}$. Dry weights of all samples and subsamples were recorded after drying. Freeze-dried subsamples were then milled with a high-speed mill equipped with a 1.0-mm screen (Tecator Cyclotec 1093 sample mill; Rose Scientific Ltd., Edmonton, Alberta, Canada) and analyzed for total carbon and $\mathrm{N}$ content using an elemental combustion system ECS Model 4010 (Costech Analytical Technologies Inc., Valencia, CA) that was calibrated using a peach leaf standard (Standard Reference Material 1547; National Institute of Standards and Technology, Gaithersburg, MD).

\section{Statistical analysis}

Data for plant tissue $\mathrm{N}$ and runoff losses of soil, N, and pesticides from all three production systems (treatments) were analyzed as a randomized complete block design using the Proc Mixed routine of the SAS program package (version 9; SAS Institute Inc., 2006). Treatment means were separated using the PDIFF option of the LSMEANS statement.

\section{Results}

Precipitation and runoff. Runoff volumes were measured per plot, and for each event, the average runoff volumes are shown in Figures 1 through 3. The duration, intensity, and total volume from each precipitation event were also calculated from weather station data. Runoff from all 42 precipitation events was measured and analyzed during the 3 -year experiment, with 16,18 , and 8 runoff events occurring in 2002, 2003, and 2004, respectively. Two frost protection events occurring on 24 Apr. 2003 and 16 Apr. 2004 were also measured. Events occurring before 29 Aug. 2002 do not include the CCP plots because these were not established until mid-Aug. 2002.

In 2002, precipitation ranged from 1 to $45 \mathrm{~mm}$ per event, the average precipitation amount was $20 \mathrm{~mm}$, and the median was 14 $\mathrm{mm}$ (Fig. 1). The average runoff volumes per event ranged from 4 to $875 \mathrm{~L}, 0$ to $659 \mathrm{~L}$, and 38 to $741 \mathrm{~L}$ for the CMR, AMR, and CCP plots, respectively. Although large variations were observed, the average runoff volumes within each event were not significantly different. The 2002 annual mean (and median) runoff volumes for the CMR, AMR, and CCP plots were $214 \mathrm{~L}$ (136 L), $213 \mathrm{~L}$ (145 L), and $352 \mathrm{~L}(261 \mathrm{~L})$, respectively. The annual mean runoff volumes for the CMR and AMR plots were not significantly different; however, the annual mean runoff volumes for both the CMR and AMR plots were significantly less than the annual mean runoff volume for CCP $(P \sim 0.01)$ (Table 2).

Three precipitation events in 2003 (Fig. 2) were of exceptional size, duration, and/or intensity and resulted in excessively high average runoff volumes (greater than $1000 \mathrm{~L}$ ) and high soil erosion (greater than $\left.75 \mathrm{~kg} \cdot \mathrm{ha}^{-1}\right)$ : 22 July $(34.5 \mathrm{~mm}$ over $3 \mathrm{~h}), 11$ Aug. (19.6 mm over $0.5 \mathrm{~h}$ ), and $18 \mathrm{Sept}$. The last of these was the result of Tropical Storm Isabel $(29 \mathrm{~mm}$ over $13 \mathrm{~h})$. Although the precipitation intensity during the tropical storm was much less than the sudden down pours on 22 July and 11 Aug., the large volume of runoff was the result of the duration of the event, high wind speeds, and saturated higher antecedent soil moisture as a result of two earlier precipitation events during that week. Thus, the following observations and calculations exclude Tropical Storm Isabel. Precipitation in 2003 ranged from 7 to $35 \mathrm{~mm}$ per event, the average precipitation amount was $17 \mathrm{~mm}$, and the median was $18 \mathrm{~mm}$. The average runoff volumes per event ranged from 0 to $3560 \mathrm{~L}$, 0 to $2960 \mathrm{~L}$, and 11 to $2290 \mathrm{~L}$ for the CMR, AMR, and CCP plots, respectively. Significant differences $(P<0.05)$ were observed in average runoff volumes for two events (Table $2)$ : average volumes from the AMR and CMR plots were greater than the CCP plots on 11 Aug. and the average runoff volume from the AMR plots was greater than the CCP plots on 27 Aug. The 2003 annual mean (and median) runoff volumes for the CMR, AMR, and CCP plots were $551 \mathrm{~L}(161 \mathrm{~L})$, $539 \mathrm{~L}(358 \mathrm{~L})$, and $421 \mathrm{~L}(263 \mathrm{~L})$, respectively. The annual mean runoff volumes for the CMR, AMR, and CCP plots were not significantly different.

Runoff events for 2004 (Fig. 3) were collected only during the spring and ended when harvest was completed in mid-June. Thus, the measured precipitation and runoff were much less as the larger mid to late summer storms were not included. The average precipitation for the events measured in 2004 was $13 \mathrm{~mm}$ and the median was $12 \mathrm{~mm}$; the events ranged from 6 to $23 \mathrm{~mm}$. The average runoff volumes per event ranged from 4 to $408 \mathrm{~L}, 0$ to $509 \mathrm{~L}$, and 11 to 476 $\mathrm{L}$ for the CMR, AMR, and CCP plots, respectively. Average runoff volumes per event were significantly different for four events in 2004: 25 Apr., 7 May, 18 May, and 11 June. On 25 Apr., the average runoff

Table 2. Runoff events with significant differences associated with variables measured between production systems (treatments). ${ }^{z}$

\begin{tabular}{|c|c|c|c|c|}
\hline $\begin{array}{l}\text { Runoff event } \\
\text { (date) }\end{array}$ & Variable & Treatment 1 & Treatment 2 & $P$ \\
\hline 29 Apr. 2002 & Soil loss & CMR & AMR & \\
\hline 13 May 2002 & Soil loss & CMR & AMR & \\
\hline 20 May 2002 & Soil loss & CMR & AMR & \\
\hline 5 Aug. 2002 & Soil loss & CMR & AMR & \\
\hline 6 Aug. 2002 & Soil loss & CMR & AMR & \\
\hline \multirow[t]{2}{*}{9 May 2003} & Azoxystrobin residues & AMR & CCP & \\
\hline & Azoxystrobin residues & CMR & CCP & \\
\hline 22 July 2003 & Azoxystrobin residues & CMR & $\mathrm{CCP}$ & \\
\hline \multirow[t]{4}{*}{11 Aug. 2003} & Runoff volume & AMR & $\mathrm{CCP}$ & $* *$ \\
\hline & Soil loss & AMR & $\mathrm{CCP}$ & \\
\hline & Soil loss & CMR & $\mathrm{CCP}$ & \\
\hline & Azoxystrobin residues & CMR & $\mathrm{CCP}$ & \\
\hline \multirow[t]{3}{*}{27 Aug. 2003} & Runoff volume & CMR & AMR & \\
\hline & Runoff volume & CMR & ССР & \\
\hline & Soil loss & AMR & $\mathrm{CCP}$ & \\
\hline 25 Apr. 2004 & Runoff volume & CMR & AMR & \\
\hline \multirow[t]{2}{*}{7 May 2004} & Runoff volume & CMR & CCP & \\
\hline & Runoff volume & AMR & CCP & \\
\hline \multirow[t]{2}{*}{18 May 2004} & Runoff volume & AMR & CCP & $* *$ \\
\hline & Runoff volume & CMR & CCP & $* *$ \\
\hline \multirow[t]{4}{*}{11 June 2004} & Runoff volume & AMR & CCP & $* * *$ \\
\hline & Runoff volume & CMR & CCP & $* *$ \\
\hline & Azoxystrobin residues & AMR & CCP & $* * *$ \\
\hline & Azoxystrobin residues & CMR & CCP & \\
\hline
\end{tabular}

${ }^{\mathrm{z}}$ Higher treatments are bolded; $P<0.05$ unless noted $(* * P<0.01 * * * P<0.001)$. 

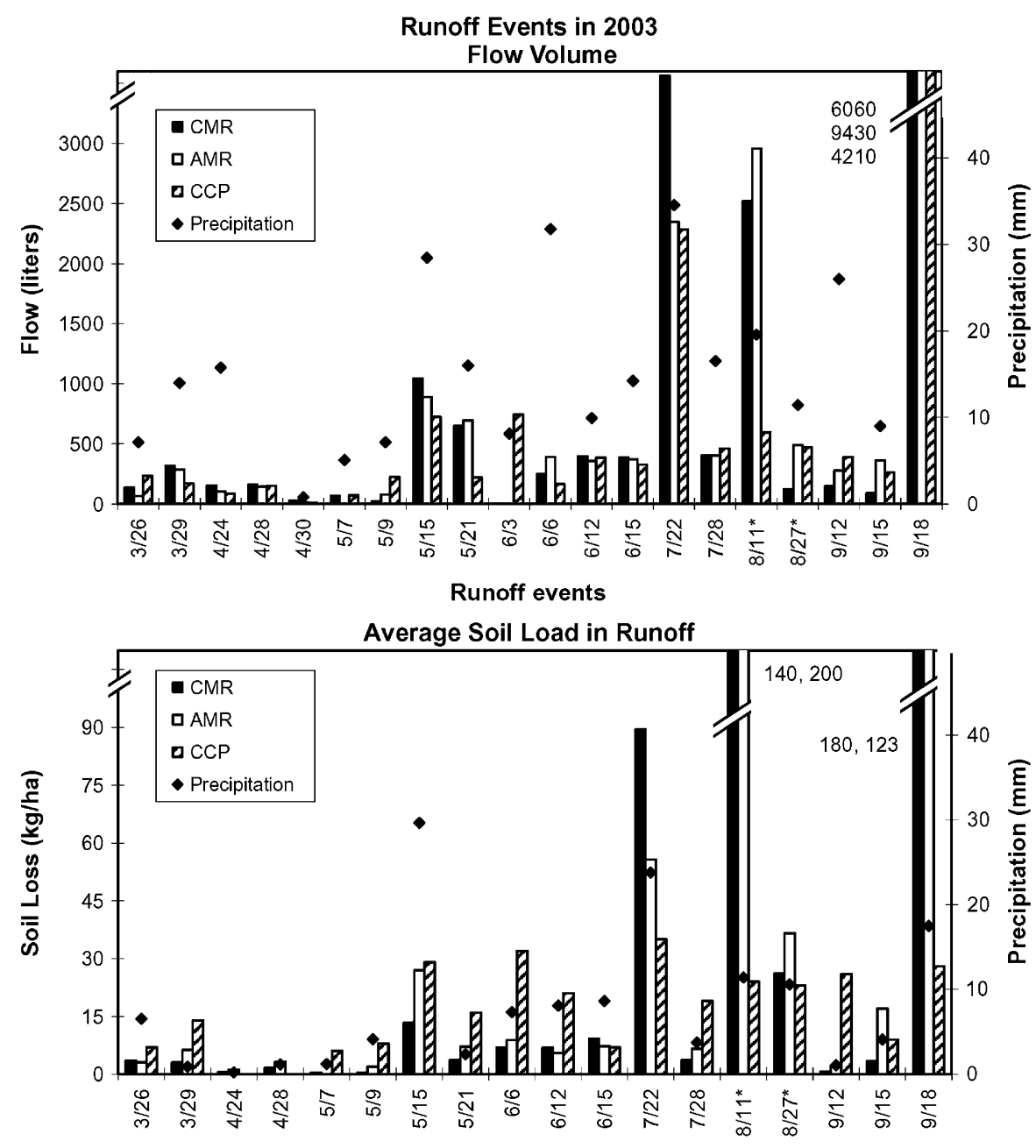

Runoff events

Fig. 2. Precipitation and average runoff volume and respective soil loss in runoff from each production system per event in 2003. Asterisk after date indicates that difference is significant between at least two treatments in runoff event. $\mathrm{CMR}=$ conventional matted row; $\mathrm{AMR}=$ advanced matted row; $\mathrm{CCP}=$ cold-climate plasticulture

volume from the AMR plots was significantly less than the average runoff volume from the CMR plots; and on the latter three dates, the average runoff volumes from both the AMR and CMR plots were significantly less than the runoff volume from the CCP plots $(P<$ 0.05; see Table 2). The 2004 annual mean (and median) runoff volumes for the CMR, AMR, and CCP plots were $128 \mathrm{~L}$ (38 L), 116 L (13 L), and $178 \mathrm{~L}(148 \mathrm{~L})$, respectively. Again, the annual mean runoff volumes for the CMR, AMR, and CCP plots were not significantly different.

Soil erosion. Soil loss $\left(\mathrm{kg} \cdot \mathrm{ha}^{-1}\right)$ was calculated based on the total volume of runoff water collected per plot per runoff event, the size of each plot, and the mass of filterable sediments per volume of runoff. Average soil losses in 2002 per event ranged from 0.1 to $270 \mathrm{~kg} \cdot \mathrm{ha}^{-1}, 0.1$ to $21 \mathrm{~kg} \cdot \mathrm{ha}^{-1}$, and 1.3 to 58 $\mathrm{kg} \cdot \mathrm{ha}^{-1}$ for the CMR, AMR, and CCP plots, respectively (Fig. 1). The average soil loss for the CMR plots was significantly greater than the average soil loss for the AMR plots in five individual events in 2002: 29 Apr., 13 May, 20 May, 5 Aug., and 6 Aug. (Table 2). All annual mean soil losses for both the CMR and AMR plots were significantly greater than the annual mean soil loss for CCP $(P<0.05)$; however, the annual mean soil loss for the CMR plots was not significantly different from the annual mean soil loss for the AMR plots.

Average soil losses per event in 2004 ranged from 0.03 to $5.4 \mathrm{~kg} \cdot \mathrm{ha}^{-1}, 0.01$ to $8.1 \mathrm{~kg} \cdot \mathrm{ha}^{-1}$, and 0.1 to $4.4 \mathrm{~kg} \cdot \mathrm{ha}^{-1}$ for the CMR, AMR, and CCP plots, respectively (Fig. 3). The average soil losses within each event were not significantly different. The annual mean (and median) soil losses for the CMR, AMR, and CCP plots were $1.9 \mathrm{~kg} \cdot \mathrm{ha}^{-1}$ $\left(0.9 \mathrm{~kg} \cdot \mathrm{ha}^{-1}\right), 2.0 \mathrm{~kg} \cdot \mathrm{ha}^{-1}\left(0.4 \mathrm{~kg} \cdot \mathrm{ha}^{-1}\right)$, and $1.9 \mathrm{~kg} \cdot \mathrm{ha}^{-1}\left(1.5 \mathrm{~kg} \cdot \mathrm{ha}^{-1}\right)$, respectively. The annual mean soil losses for the CMR, AMR, and $\mathrm{CCP}$ plots were not significantly different.

Pesticide runoff. No insecticides were used over the course of the study because insect pressures were minimal as was determined during regular scouting inspections of the plots. Four fungicides, captan, benomyl, thiophanate-methyl, and azoxystrobin, were used to control disease (Table 1). Azoxystrobin was applied twice in both 2003 and 2004 (Fig. 4). The ranges of the average loads in runoff per event, where azoxystrobin concentrations were above the limit of detection, were 0.1 to $384 \mathrm{mg} \cdot \mathrm{ha}^{-1}, 0.1$ to $116 \mathrm{mg} \cdot \mathrm{ha}^{-1}$, and 0.1 to $92 \mathrm{mg} \cdot \mathrm{ha}^{-1}$ for the CMR, AMR, and CCP plots, respectively. The differences in loads were significant for four events (Table 2). For the events of 9 May 2003 and 11 June 2004, the average azoxystrobin loads from the CCP plots were greater than the average loads from both the CMR and AMR plots; and for the events of 22 July 2003 and 11 Aug. 2003, the loads were greater from the CMR plots than the loads from the AMR and CCP plots, respectively.

Benomyl was applied only once in 2003 and was detected in most of the runoff events in 2003 after application (Fig. 5). The ranges of the average loads in runoff per event, where benomyl concentrations were above the limit of detection, were 3.08 to 532 $\mathrm{mg} \cdot \mathrm{ha}^{-1}, 2.46$ to $156 \mathrm{mg} \cdot \mathrm{ha}^{-1}$, and 2.46 to $299 \mathrm{mg} \cdot \mathrm{ha}^{-1}$ for the CMR, AMR, and CCP plots, respectively. Captan was used twice but was not detected in any runoff samples at any time. Thiophanate-methyl was applied once in 2003 and 2004 (Fig. 6). The ranges of the average loads in runoff per event, where thiophanate-methyl concentrations were above the limit of detection, were 0.1 to $464 \mathrm{mg} \cdot \mathrm{ha}^{-1}$, 0.1 to $152 \mathrm{mg} \cdot \mathrm{ha}^{-1}$, and 0.4 to $329 \mathrm{mg} \cdot \mathrm{ha}^{-1}$ for the CMR, AMR, and CCP plots, respectively. Neither the average benomyl loads per event nor the average thiophanate-methyl loads per event were significantly different among the CMR, AMR, and CCP treatments.

Three herbicides were used during the study: 2,4-D, paraquat, and glyphosate (Table 1). Glyphosate was used only on the AMR plots and was applied before activation of runoff samplers; therefore, no data exist for glyphosate loss by runoff. 2,4-D was applied once to the CMR and AMR plots during renovation but was not detected in any runoff samples. Paraquat was applied once to 
Runoff Events in 2004

Flow Volume

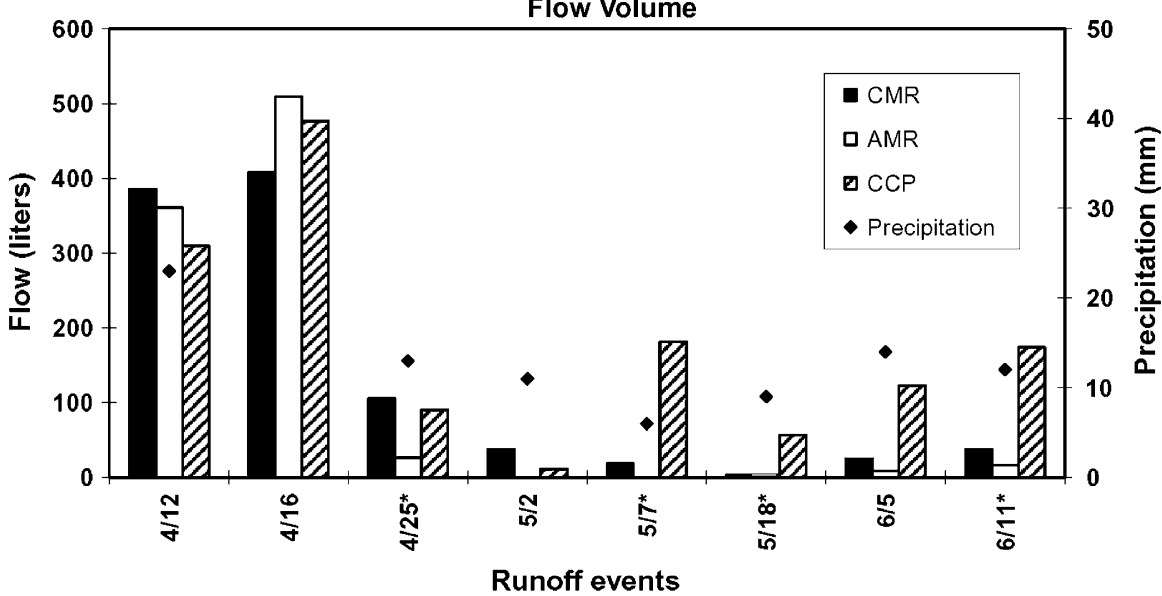

Runoff events

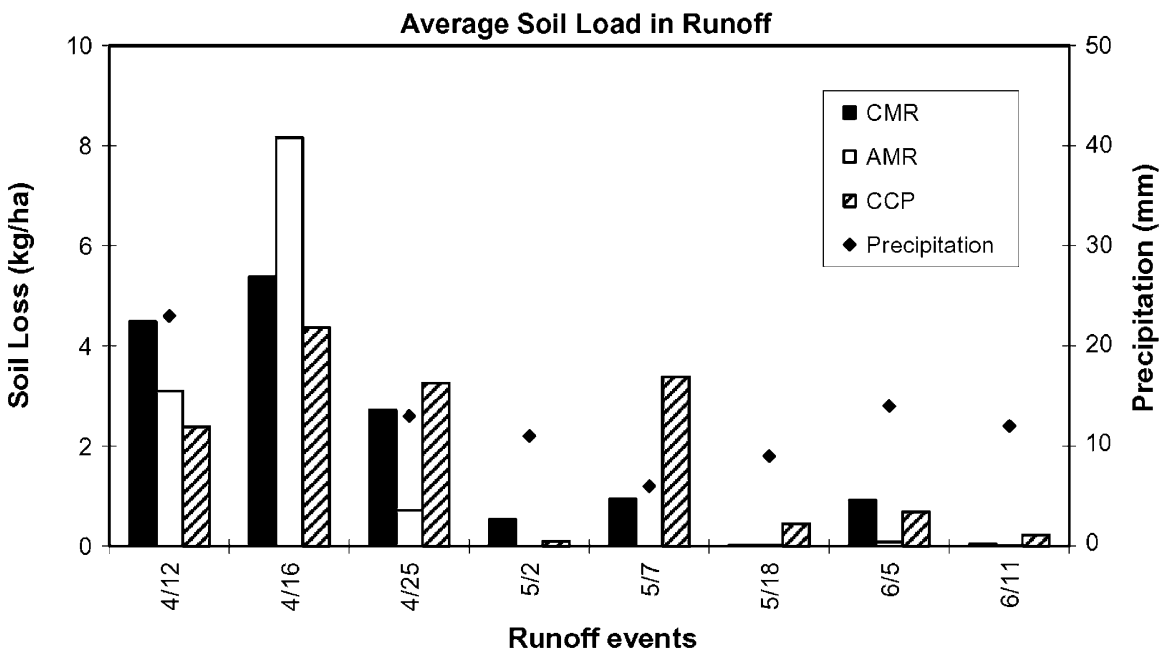

Fig. 3. Precipitation and average runoff volume and respective soil loss in runoff from each production system per event in 2004. Asterisk after date indicates that difference is significant between at least two treatments in runoff event. $\mathrm{CMR}=$ conventional matted row; $\mathrm{AMR}=$ advanced matted row; $\mathrm{CCP}=$ cold-climate plasticulture.

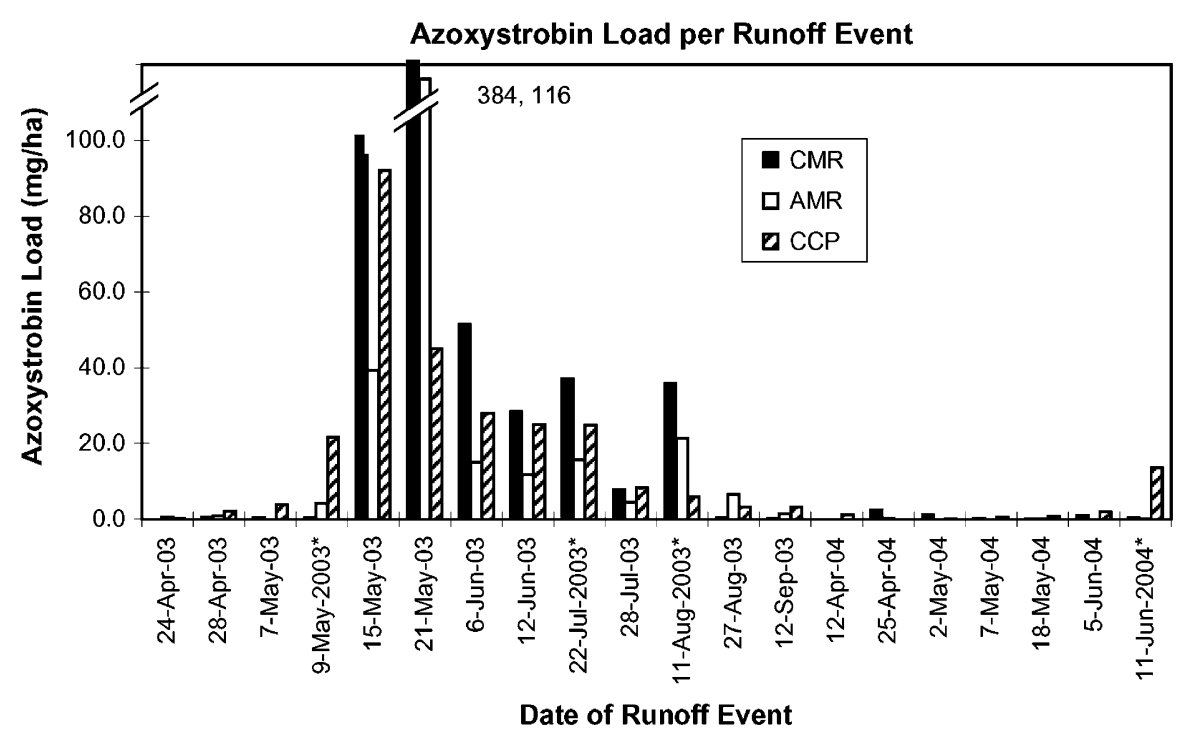

Fig. 4. Average azoxystrobin load in runoff from each production system per precipitation event. Azoxystrobin was applied on 5 May 2003, 16 May 2003, 12 Apr. 2004, and 26 Apr. 2004. Asterisk after date indicates that difference is significant between at least two treatments in runoff event. $\mathrm{CMR}=$ conventional matted row; $\mathrm{AMR}=$ advanced matted row; $\mathrm{CCP}=$ cold-climate plasticulture . the CMR plots and multiple times to both the AMR and CCP plots but was only detected in one runoff event. No significant differences in paraquat losses were observed between production systems for this event (data not shown).

Nitrogen runoff and plant uptake. The fertilizer method, timing, and rate of application were different for each production system; thus, the results for ammonia and nitrate/nitrite $\mathrm{N}$ runoff from individual events cannot be compared directly. The role of nutrients in the overall environmental footprint of each of the three practices was considered by examining the total $\mathrm{N}$ applications, $\mathrm{N}$ losses, plant uptake of $\mathrm{N}$, and plant $\mathrm{N}$ uptake efficiency, which are shown in Table 3. Attempts to measure leached $\mathrm{N}$ in the soil profile were not successful because rainfall and irrigation were not sufficient to cause enough percolation to the suction lysimeters for adequate sample volume. Some amount of $\mathrm{N}$ in each of the three production systems was taken up by the fruit. Black et al. (2005) reported $0.666 \mathrm{mg} \mathrm{N} / \mathrm{g}$ fruit (fresh weight) for 'Allstar' in the AMR system. Fruit N uptake was not accounted for in this study as a result of the timing of destructive tissue harvest. Furthermore, a complete mass balance of $\mathrm{N}$ was not possible in all practices; unrecovered $\mathrm{N}$ was presumably lost either through ammonia volatilization and/or through denitrification, although neither process was evaluated or measured.

The CMR plots received several large broadcast applications of $\mathrm{NH}_{4} \mathrm{NO}_{3}$ annually, whereas the CCP and AMR plots received small, weekly applications of $\mathrm{NH}_{4} \mathrm{NO}_{3}$ through a drip irrigation system. Although the $\mathrm{N}$ application rate was similar for all three production systems, the total amount of $\mathrm{N}$ applied per plant was greatest in the CMR plots followed by the AMR plots and then the CCP plots. Significantly higher losses of N were observed in runoff from the CMR plots as compared with $\mathrm{N}$ losses in runoff from both the AMR and CCP plots; $\mathrm{N}$ losses in runoff from the AMR plots were also significantly higher than the $\mathrm{N}$ losses from the $\mathrm{CCP}$ plots. Although the total $\mathrm{N}$ applied per plant was lowest in the CCP plots, plant uptake efficiency was significantly higher than the other production systems; CMR plots had the least efficient plant $\mathrm{N}$ uptake.

\section{Discussion}

The effects of three strawberry production systems on environmental resources were examined in this study. In general, the differences among the CMR, AMR, and CCP systems were found to be statistically more significant with smaller runoff events primarily because of the low variability between replicates. Likewise, for larger events, the differences were less significant presumably as a result of the smaller variation among the three practices relative to other factors. The results suggest that the quantity and quality (intensity and duration) of the precipitation event and timing of the precipitation relative to specific agronomic events (for example, 


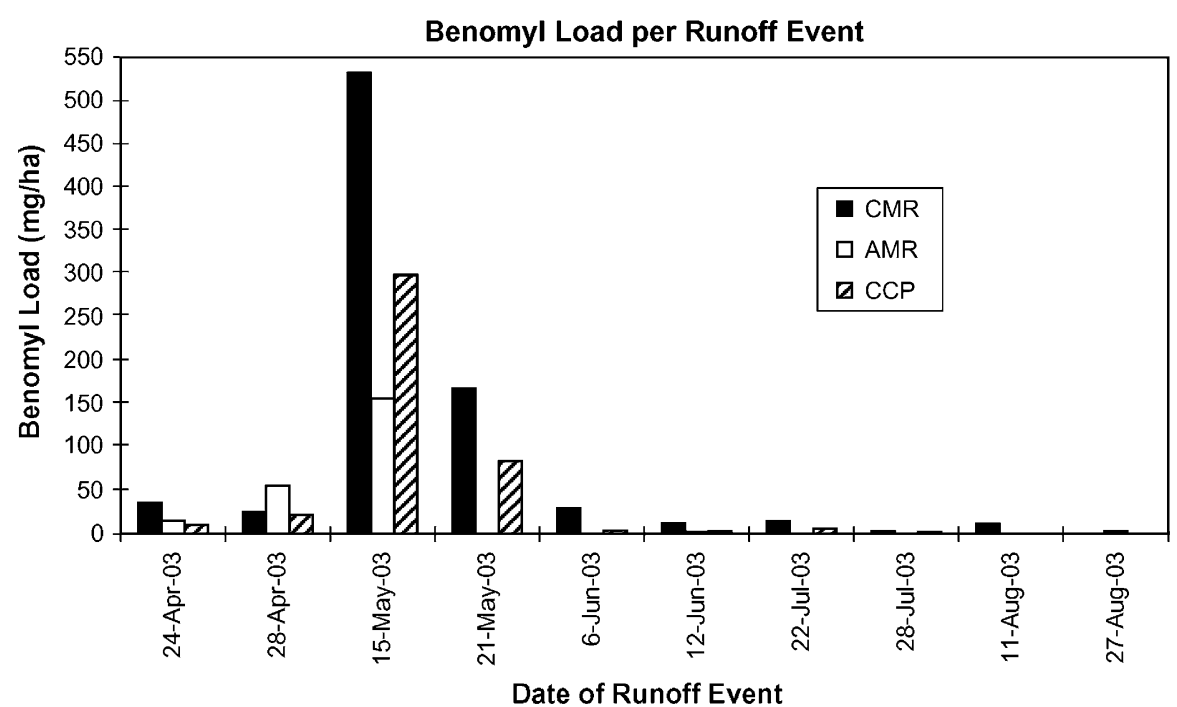

Fig. 5. Average benomyl load in runoff from each production system ice per precipitation event. Benomyl was applied on 22 Apr. 2003. $\mathrm{CMR}=$ conventional matted row; $\mathrm{AMR}=$ advanced matted row; $\mathrm{CCP}=$ cold-climate plasticulture.

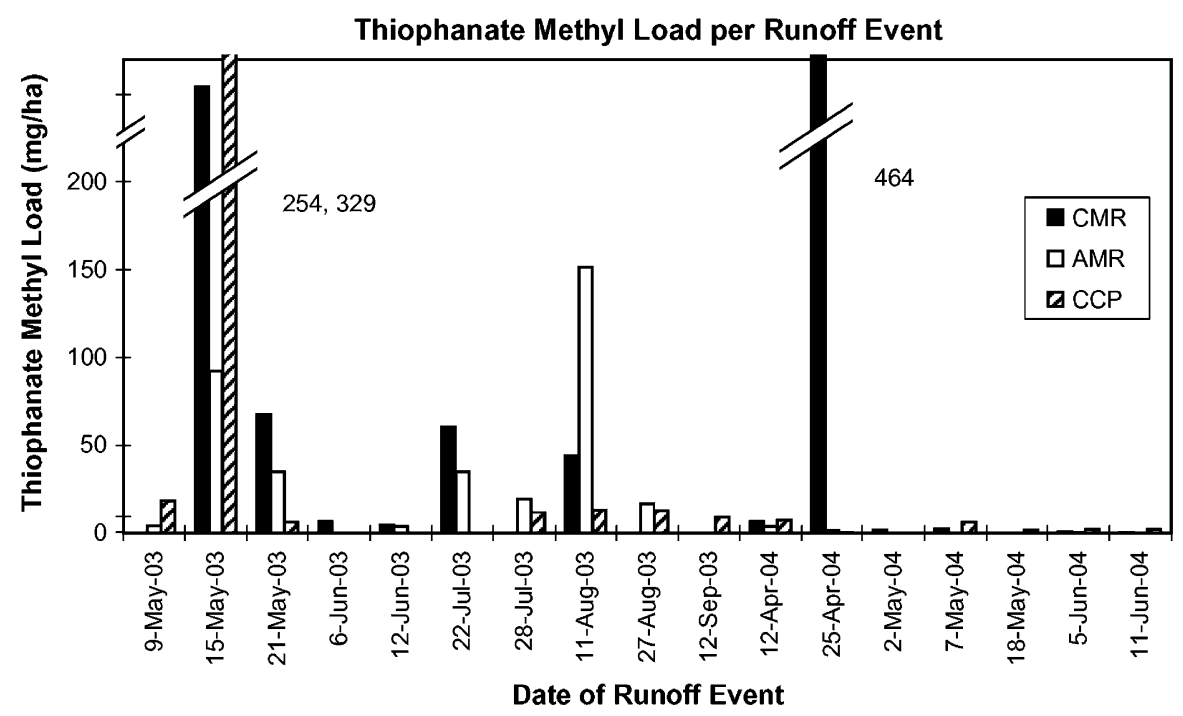

Fig. 6. Average thiophanate-methyl load in runoff from each production system per precipitation event. Thiophanate-methyl was applied on 13 May 2003 and 19 Apr. 2004. CMR = conventional matted row; $\mathrm{AMR}=$ advanced matted row; $\mathrm{CCP}=$ cold-climate plasticulture

Table 3. Mass balance of nitrogen $(\mathrm{N})$ components: $\mathrm{N}$ application rate, $\mathrm{N}$ applied per plant, total plant $\mathrm{N}$ uptake, total $\mathrm{N}$ in runoff, total $\mathrm{N}$ recovered, and plant $\mathrm{N}$ uptake efficiency for three strawberry production systems. $^{z}$

\begin{tabular}{lcccccc}
\hline & $\begin{array}{c}\text { Application } \\
\text { rate } \\
\text { Treatment }\end{array}$ & $\begin{array}{c}\text { Total N } \\
\text { applied } \\
\left(\mathrm{kg} \cdot \mathrm{ha}^{-1} \mathrm{~N}\right)\end{array}$ & $\begin{array}{c}\text { Total N } \\
\text { runoff } \\
(\mathrm{g} / \mathrm{plant})\end{array}$ & $\begin{array}{c}\text { Total plant } \\
\text { N uptake } \\
(\mathrm{g} / \mathrm{plant})\end{array}$ & $\begin{array}{c}\text { Plant N uptake } \\
\text { efficiency } \\
(\%)\end{array}$ & $\begin{array}{c}\text { Total N } \\
\text { recovered } \\
(\%)\end{array}$ \\
\hline CMR & 170.4 & 10.77 & $0.22 \mathrm{a}$ & 1.73 & $16.1 \mathrm{c}$ & $18.1 \mathrm{c}$ \\
AMR & 229.8 & 6.49 & $0.11 \mathrm{~b}$ & 2.01 & $31.0 \mathrm{~b}$ & $32.7 \mathrm{~b}$ \\
CCP & 173.7 & 2.33 & $0.01 \mathrm{c}$ & 1.78 & $76.4 \mathrm{a}$ & $76.8 \mathrm{a}$ \\
\hline
\end{tabular}

${ }^{\mathrm{z}}$ Means followed by different letters are significant $(P<0.05)$.

$\mathrm{CMR}=$ conventional matted row $\mathrm{AMR}=$ advanced matted row $\mathrm{CCP}=$ cold-climate plasticulture.

tilling, weeding, and formation of the beds) affected the soil and pesticide losses and runoff volume more than the type of production system.

This phenomenon was most effectively demonstrated by the events of Summer 2003.
Before the 22 July 2003 precipitation event, the CMR plots were cultivated and before the 11 Aug. 2003 event, the AMR plots were cultivated. Concomitantly, average soil losses were lower from the CCP plots, which were undisturbed. In April and May 2002, significantly greater soil losses were observed from the bare soil CMR plots relative to the AMR plots, which were covered by a cover crop residue layer. On 5 Aug. 2002, the CMR plots lost 10 times more soil than the AMR plots, and again, the CMR plots lost significantly more soil on 6 Aug. 2002, because cultivation was performed before these events. The CCP plots were installed on 21 Aug. 2002 and large soil losses from the CCP were observed in most of the subsequent runoff events in 2002. In all these events, larger soil losses were observed from the plots that had been most recently tilled.

The environmental footprint of production is also a function of the pollutants released to the surrounding ecosystems. The discharge of nutrients from production fields and into nearby streams and larger water bodies is a major concern in areas where cold-climate strawberries are produced. Timing and placement of fertilizer $\mathrm{N}$ were found to be critical in the CMR plots, which had lower $\mathrm{N}$ uptake efficiencies and higher amounts of $\mathrm{N}$ in the runoff. Alternatively, both the AMR and CCP plots used drip fertigation, which is buried several centimeters below the soil surface and had significantly higher $\mathrm{N}$ uptake efficiencies and lower $\mathrm{N}$ in the runoff compared with the CMR plots where the fertilizer was broadcast.

In addition to the nutrients and sediments in the runoff, pesticides can render the runoff more toxic. The toxicity of the runoff is dependent on the pesticide concentration, the species affected, and the mode of action of the pesticide. In general, herbicides are less toxic to most nonplant aquatic organisms as compared with fungicides (Pait et al., 1992). The fungicides used in this study have a moderate to high acute toxicity for aquatic organisms with $\mathrm{LC}_{50} \mathrm{~s}(96 \mathrm{~h})$ ranging from 50 $\mathrm{ppb}$ to $25 \mathrm{ppm}$ for rainbow trout (Table 1). In contrast, the $\mathrm{LC}_{50} \mathrm{~s}$ for the herbicides ranged from 1 to $100 \mathrm{ppm}$. The concentrations of the pesticides measured in the runoff in this study were generally well below these ranges. Furthermore, runoff samples with maximum concentrations of the fungicides $(0.0252$ ppm, $0.0515 \mathrm{ppm}$, and $0.3305 \mathrm{ppm}$ for azoxystrobin, benomyl, and thiophanatemethyl, respectively) were at least an order of magnitude lower than the reported $\mathrm{LC}_{50} \mathrm{~s}$. Pesticide losses in this experiment were generally limited from the AMR plots as compared with the CMR and CCP plots; the greatest pesticide losses occurred mostly from the CMR plots.

This study does not include the environmental issues of the manufacturing of purchased inputs such as plastic mulch, drip tape, fertilizers, or pesticides nor does it include the disposal of the plastic mulch and drip tape. The results indicate 1) that the CMR system was least effective in controlling soil and pesticide losses; 2) that overall, the AMR system was most effective for erosion control in the first year, whereas the CCP system was generally better in the second year; and 3 ) that the lowest pesticide residues occurred in runoff from the AMR 
system. These observations suggest that the AMR and CCP systems have less negative effects on our natural resources than the CMR system. Furthermore, given that the plastic mulch is nonrenewable and must be disposed of in a landfill, the AMR system is a more environmentally sustainable production system.

\section{Literature Cited}

Bengston, R.L., L.M. Southwick, G.H. Willis, and C.E. Carter. 1990. The influence of subsurface drainage practices on herbicide losses. Transactions of the American Society of Agricultural Engineers. 33:415-418.

Black, B.L., J.E. Enns, and S.C. Hokanson. 2002a. Advancing the matted-row strawberry production system, p. 112-115. In: Hokanson, S.C. and A.R. Jamieson (eds.). Strawberry research to 2001. ASHS Press, Alexandria, VA.

Black, B.L., J.M. Enns, and S.C. Hokanson. 2002b. A comparison of temperate-climate strawberry production systems using eastern genotypes. HortTechnology 12:670-675.

Black, B.L., S.C. Hokanson, and K.S. Lewers. 2005. Fruit nitrogen content of sixteen strawberry genotypes grown in an advanced matted row production system. HortScience 40:1190-1193.

Brush, G.S. and W.B. Hilgartner. 2000. Paleoecology of submersed macrophytes in the upper Chesapeake Bay. Ecol. Monogr. 70:645-667.

Clark, J.R., M.A. Lewis, and A.S. Pait. 1993. Pesticide inputs and risks in coastal wetlands. Environ. Toxicol. Chem. 12:2225-2233.

Forney, D.R. and D.E. Davis. 1981. Effects of low concentrations of herbicides on submersed aquatic plants. Weed Sci. 29:677-685.

Jones, T.W. and L. Winchell. 1984. Uptake and photosynthetic inhibition by atrazine and its degradation products on four species of submerged vascular plants. J. Environ. Qual. 13:243-247.

Lea-Cox, J.D. and D.S. Ross. 2001. A review of the federal clean water act and the Maryland water quality improvement act: The rationale for developing a water and nutrient management planning process for container nursery and greenhouse operations. Journal of Environmental Horticulture. 19:226-229.

Leonard, R.A., G.W. Langdale, and W.G. Fleming. 1979. Herbicide runoff from Upland Piedmont watersheds - Data and implications for modeling pesticide transport. J. Environ. Qual. 8:223-229.

O'Dell, C.R. and Williams, J. 2000. Hill system plastic mulched strawberry production guide for colder areas. Publication 438-018, Virginia Cooperative Extension, Virginia Tech, Blacksburg, VA.

Pait, A.S., A.E.D. Souza, and D.R.G. Farrow. 1992 Agricultural pesticide use in coastal areas: A national summary, 112 pp. NOAA/NOS/ ORCA, Silver Spring, MD.

Poling, E.B. and D.W. Monks. 1994. Strawberry plasticulture guide for North Carolina. NCCES AG-505. 5 Jan. 2009. <http://www.smallfruits.org/ Strawberries/production/StPlastG/ncplas.htm>.

Pritts, M.P. and D.M. Handley. 1998. Strawberry production guide for the northeast, midwest, and eastern Canada. NRAES 88:1-62.

Rice, P.J., L.L. McConell, L.P. Heighton, A.M. Sadeghi, A.R. Isensee, A.A. Abdul-Baki, J.A. Harman-Fetcho, and C.J. Hapeman. 2002. Transport of copper in runoff from freshmarket vegetable production using polyethylene mulch or a vegetative mulch. Environ. Toxicol. Chem. 21:24-30.

SAS Institute Inc. 2006. SAS online doc. Version 9. SAS Institute Inc, Cary, NC.
Savitz, J.D., D.A. Wright, and R.A. Smucker. 1994. Toxic effects of the insecticide diflubenzuron (Dimilin) on survival and development of Napulii of the Estuarine Copepod, Eurytemora affinis. Mar. Environ. Res. 37:297-312.

Scott, G.I., M.H. Fulton, M.C. Crosby, P.B. Key, J.W. Daugomah, J.T. Waldren, E.D. Strozier, C.J. Louden, G.T. Chandler, T.F. Bidleman, K.L. Jackson, T.W. Hampton, T. Huffman, A. Shulz, and M. Bradford. 1994. Agricultural insecticide runoff effects on estuarine organisms: Correlating laboratory and field toxicity tests, ecophysiology bioassays, and ecotoxicological biomonitoring. EPA/600/R-94/004:288.

Steiner, P.W., R. Heflebower, and R. Rouse. 1999. Maryland commercial small fruit production guide. MCES 242, 8 pp. University of Maryland Cooperative Extension, College Park, MD.

Stevens, M.D. 2005. Sustainability of cold-climate strawberry production systems. MS Thesis, University of Maryland.

Triplett G.B., Jr., B.J. Conner, and W.M. Edwards. 1978. Transport of atrazine and simazine in runoff from conventional and no-tillage corn. J. Environ. Qual. 7:77-84.

USDA-ERS. 2007. U.S. strawberry harvested acreage, yield per acre, and production, 13 States, 1970-2006. 5 Jan. 2009. <http://usda.mannlib. cornell.edu/usda/ers/95003/table04.xls $>$.

USEPA. 1994. National Water Quality Inventory: 1994 Report to Congress. 5 Jan. 2009. <http:/ www.epa.gov/305b/94report/index.html>.

USEPA. 1998. Water Quality Assessment and Total Maximum Daily Loads Information (ATTAINS). 5 Jan. 2009. <http://www.epa. gov/waters/ir/>

Wauchope, R. 1996. Pesticides in runoff: Measurement, modeling, and mitigation. J. Environ. Sci. Health B31:337-344. 